\title{
Cambridge
}

\section{How to Write and Publish}

a Scientific Paper

\section{Third Edition}

\section{ROBERT A. DAY}

Save time and improve the appearance and accuracy of your work with this new edition of the definitive 'how-to' book.

- easy to use, tried and tested format

designed specifically for use by the scientist

up-to-date information on electronic manuscripts and new computer techniques

covers all forms of publishing from journal articles to complete books

This new edition contains advice, hints and guidelines for all stages of writing, from the selection of a title to dealing with editors. It includes practical advice on grammar, proof reading, tables and illustrations and a list of commonly used and misused abbreviations, expressions and terms.

With sales of the first and second editions topping 100,000 copies this new edition is bound to become a standard reference for all scientists.

£20.00 net $\mathrm{Hc} \quad 0 \quad 521365724$ £7.95 net $\mathrm{Pb} \quad 0521367603$ 244 pp. 1989

For further information on this, and other C.U.P. science titles, please write to Jacqueline Arthurs at the address below. 
The effectiveness of a prenatal education programme for the prevention of congenital toxoplasmosis

Carter, A. O., Gelmon, S. B., Wells, G. A. and Toepell, A. P.

Esterase electrophoresis: a molecular tool for studying the epidemiology of

Branhamella catarrhalis nosocomial infection

Picard, B., Goullet, Ph., Denamur, E. and Suermondt, G.

Genotyping of Pseudomonas aeruginosa sputum and stool isolates from cystic fibrosis

patients : evidence for intestinal colonization and spreading into toilets

Döring, G., Bareth, H., Gairing, A., Wolz, C. and Botzenhart, K.

Multiresistant serotype 012 Pseudomonas aeruginosa : evidence for a common strain in Europe

Pitt, T. L., Livermore, D. M., Pitcher, D., Vatopoulos, A. C. and Legakis, N. J.

Response of the chick embryo to live and heat-killed Campylobacter jejuni injected into the yolk sac

Clark, A. G. and Bueschkens, D. H.

Immunity against diphtheria in adults in Poland

Galazka, A. and Kardymowicz, B.

Electrophoretic characterisation of the outer membrane proteins of Yersinia pestis isolated in north-east Brazil

Abath, F. G. C., Almeida, A. M. P. and Ferreira, L. C. S.

The survival patterns of selected faecal bacteria in tropical fresh waters

Wright, R. C.

Laboratory diagnosis of Mycoplasma pneumoniae infection. 3. Detection of IgM

antibodies to $M$. pneumoniae by a modified indirect haemagglutination test

Kok, T. W., Marmion, B. P., Varkanis, G., Worswick, D. A. and Martin, J.

Lymphoproliferative response to fusion proteins of human papillomaviruses in

patients with cervical intraepithelial neoplasia

Cubie, H. A., Norval, M., Crawford, L., Banks, L. and Crook, T.

Influenza mortality and excess deaths in the elderly, 1967-82

Sprenger, M. J. W., Van Naelten, M. A. M. G., Mulder, P. G. H. and Masurel, N.

Laboratory diagnosis and clinical significance of rubella in children with cancer

Morris, D. J., Morgan-Capner, P., Wood, D. J., Dalton, M., Wright, J., Thomas, H. I. J. and Stevens, R. F.

A time series analysis of the rabies control programme in Chile

Ernst, S. N. and Fabrega, F.

The time course of the humoral immune response to rhinovirus infection

Barclay, W. S., Al-Nakib, W., Higgins, P. G. and Tyrrell, D. A. J.

Restricted variability of a 17 nucleotide stretch within the 5 -noncoding region

of poliovirus genome

Pöyry, T., Kinnunen, L. and Hovi, T.

Bancroftian filariasis in Pondicherry, South India: 1. Pre-control epidemiological observations

Rajagopalan P. K., Das, P. K., Subramanian S., Vanamail, P. and Ramaiah, K. D.

Bancroftian filariasis in Pondicherry, South India: 2. Epidemiological evaluation of the effect of vector control

Subramanian S., Pani, S. P., Das, P. K. and Rajagopalan, P. K.

An outbreak of waterborne cryptosporidiosis caused by post-treatment contamination

Smith, H. V., Patterson, W. J., Hardie, R., Greene, L. A., Benton, C., Tulloch, W., Gilmour,

R. A., Girdwood, R. W. A., Sharp, J. C. M. and Forbes, G. I.

Notes for Contributors 


\section{Epidemiology and Infection}

\section{Original reports and reviews on all aspects of infection of man and animals}

\section{CONTENTS}

Special Article. Susceptibility of enterococci and epidemiology of enterococcal infection in the 1980 s.

George, R. C. and Uttley, A. H. C.

Salmonella enteritidis phage type 4 from the contents of intact eggs: a study involving naturally infected hens

Humphrey, T. J., Baskerville, A., Mawer, S., Rowe, B. and Hopper, S.

A large outbreak of Salmonella enteritidis phage type 4 associated with eggs from overseas

Stevens, A., Joseph, C., Bruce, J., Fenton, D., O'Mahony, M., Cunningham, D., O'Connor, B. and Rowe, B.

Numerical index of the discriminatory ability of biotyping for strains of Salmonella typhimurium and Salmonella paratyphi B

Old, D. C. and Barker, R. M.

An outbreak of paratyphoid fever in the UK associated with a fish-and-chip shop

Francis, S., Rowland, J., Rattenbury, K, Powell, D., Rogers, W. N., Ward, L. and Palmer, S. R.

Staphylococcal food poisoning from sheep milk cheese

Bone, F. J., Bogie, D. and Morgan-Jones, S. C.

Hospital dispersion of Staphylococcus epidermidis isolates resistant to a

fluoroquinolone, perfloxacin

Etienne, J., Brun, Y., Billard, M. and Fleurette, J.

The effects of pre-enrichment on recovery of Streptococcus agalactiae,

Staphylococcus aureus and mycoplasma from bovine milk

Thurmond, M. C., Tyler, J. W., Luiz, D. M., Holmberg, C. A. and Picanso, J. P.

Comparative study of visual inspections and microbiological sampling in premises manufacturing and selling high-risk foods

Tebbut, G. M. and Southwell, J. M.

Restriction endonuclease characterization of resistant plasmids in Enterobacteriaceae isolated from children in the Sudan

Shears, P., Suliman, G. and Hart, C. A.

Enterotoxigenic Escherichia coli in the domestic environment of a Malaysian village Vadivelu, J., Feachem, R. G., Drasar, B. S., Harrison, T. J., Parasakthi, N., Thambypillai, V. and Puthucheary, S. D.

Direct transmission of Escherichia coli from poultry to humans

Ojeniyi, A. A.

Some observations on the faecal carriage of mesophilic Aeromonas species in cows and pigs

Gray, S. J. and Stickler, D. J.

\section{Cambridge University Press}

The Pitt Building, Trumpington Street, Cambridge CB2 1RP

40 West 20th Street, New York, NY 10011, USA

10 Stamford Road, Oakleigh, Melbourne, 3166, Australia 